\title{
THE ROLE OF ROSE(RAPID ONSITE EVALUATION) ON SPINAL LESION SURGERY DECISION
}

\author{
Sindrawati ${ }^{1), 3)}$, Komang Agung ${ }^{2), 3)}$, Carlos Binti ${ }^{3)}$, Anggita Dewi ${ }^{3)}$
}

\begin{abstract}
Introduction: Exposure and instrumentation of the spine must be meticulous and thorough regardless the techniques and approach selected. Management of the whole surgery process should be decided based on the best available evidence whenever possible. ROSE (Rapid Onsite Evaluation) cytology wrap up the surgical decision. Case Description: Fifteen cases comprise of lytic lesions and/or single pathological fractures of the corpus vertebrae will be presented and discuss as to how the surgical techniques and approaches are assisted by ROSE. ROSE cytology was performed in the operating theater during the surgery. Samples were taken after exposure of the minimal lesion using (18-21) G trocar needle or under fluoroscopy guided. Direct smear, air dried fixation, and Diff Quik staining would take about 10 minutes. Pathologist evaluated the specimen and provided the result in about 20 minutes. The overall 30 minutes allowed surgeon to prepare the further steps. Results would be malignant or benign without pursuing further detail diagnostic. Benign results should be categorized as infection, suspicious of granulomatic tuberculosis, or normal host population cells. The cases outcome were 8 normal host population cells advanced for vertebroplasty to fill the porotic bone. Three spondylitis tuberculosis were debrided without unnecessary instrumentation, and four malignant processes were assured to have enough samples for immunohistochemistry evaluation afterward. All ROSE cytology was confirmed accordingly by the histopathology result afterward. Conclusion: ROSE is easy and offers accurate sampling from the lesion itself. It is quick, therefore during surgery surgeon could decide the best management for the patient.
\end{abstract}

Keyword: Rapid Onsite Evaluation Cytology, Intraoperative Cytology

\section{ABSTRAK}

Pendahuluan: Pembedahan canggih endoskopik untuk lesi spinal harus direncanakan dan dikerjakan dengan teliti dan penuh perhitungan berbasis bukti. Dengan pemeriksaan ROSE; pemeriksaan bahan biopsi dilakukan segera saat penderita masih di meja operasi; akan membantu penentuan jenis operasi yang tepat, tidak jarang berbeda dengan rencana semula. 
Presentasi Kasus: Dilaporkan 15 kasus pembedahan lesi litik spinal dan atau disertai fraktur kompresi vertebra dengan bantuan teknik ROSE. Pemeriksaan ROSE merupakan pemeriksaan sitologi intraoperatif dari sampel biopsi yang diambil dengan jarum trokar (1821) G disertai tuntunan fluoroskopi ataupun pada ekspose insisi minimal. Bahan biopsi diletakkan pada gelas kaca untuk dibuat hapusan, diproses seperti sediaan FNAB; keseluruhan proses adalah 10 menit. Dokter patologi memeriksa mikroskopik langsung dan melaporkan kepada dokter bedah dalam 20 menit sehingga keseluruhan waktu tunggu 30 menit dapat digunakan dokter bedah untuk menyiapkan tindakan bedah lanjutan yang sesuai dengan hasil temuan awal tersebut. Hasil ROSE didiskusikan dengan dokter bedah apakah cukup berupa penentuan ganas atau jinak tanpa diagnosa penyebab tertentu, atau diharapkan suatu diagnosa yang mengarah suatu penyakit tertentu. Apabila didapatkan suatu infeksi maka kepastian adanya proses Tuberculosa sangat diharapkan. Segera dilakukan pulasan ZN untuk melihat adanya batang tahan asam. Dilaporkan 8 kasus tanpa neoplasma sehingga segera dilakukan vertebroplasti untuk mengisi korpus vertebra yang gepeng. Empat kasus keganasan harus dilaporkan kecukupan bahan biopsy untuk pemeriksaan lanjutan penentuan diganosa dengan Immunohistokimia. Tiga kasus TBC segera dilakukan pembersihan jaringan nekrotik yang berbeda dengan kasus infeksi biasa. Semua bahan biopsy tersebut dilanjutkan dengan pemeriksaan histopatologi sebagai gold standard dan keseluruhan hasil sesuai dengan laporan awal ROSE. Kesimpulan: ROSE berperan dalam perencaan strategi tindakan operasi lesi spinal karena mudah dan akurat.

Kata Kunci: Rapid Onsite Evaluation Cytology, Intraoperative Cytology

1) Medical Faculty, Widya Mandala Catholic University Surabaya. 2) Dr. Soetomo General Hospital,

Airlangga University Medical Faculty. 3) Surabaya Orthopedi \& Traumatology Hospital

Email : oensindrawati@gmail.com

\section{INTRODUCTION}

Rapid on site evaluation (ROSE) is a direct cytology evaluation while the procedure is being conducted. ${ }^{1,2}$ ROSE will be able to provide confirmed adequate sample for diagnostic purposes. ${ }^{1,2,3}$ The value of ROSE is to optimize the benefit of the procedure for patient and doctor as well; for the shake of accurate treatment plan, for the convenience of a single-step surgery process, and for economic reasons. $^{3,4,5}$

Not infrequently the clinical and imaging data render similar possible diagnostic which lead to different techniques and approach., ${ }^{4,5,6}$ Lytic lesions 
or single pathological fracture are the most dispute cases which may be caused by neoplastic, inflammation, or a degenerative process. ${ }^{4,6,7}$ When there's window in the periosteum, fine needle aspiration biopsy (FNAB) could be arranged prior to surgery, yet for single lytic or fractured lesion, FNAB is not an option. $^{3,4,7}$ Frozen section examination during spinal surgery was history. ${ }^{1,3,6,7}$

ROSE has now become a developed procedure, specimen is directly imprinted or spread in FNAB way (fig.1a). Slides are examined, and report is delivered within minutes without waiting for 3 days histopathology result, circumvent the second surgery. ${ }^{2,3,5}$ This is a case series of 15 ROSE intra-operative cytological examination of vertebral lesions. We aim to evaluate the benefit for the patients and the doctors in charge.

\section{CASE PRESENTATION}

We report 15 cases of ROSE assisted spinal lesion surgery performed in the operating theater in the course of the procedure. This study has been approved by the Internal Institutional Review Board. Cases were indicated when onsite pathological findings could converse the surgical decision. Vertebral lytic lesion with or without compression fracture in elderly with a history of a malignant disease without convincing tumor marker elevation could be caused by osteoporosis process or metastatic process. The porotic bone would be filled with bone filler to strengthen and to elevate the compressive vertebral body. In metastatic lesions, specimen should be prepared enough for further immuno-histological evaluation. These cases might not need to get unnecessary expensive bone filler.

Mass and bone destructive spinal lesions could be caused by malignancy or severe infection, such as Tuberculoses which is endemic in Indonesia. Intraoperative findings with rapid AcidFast staining may support surgeons to affirm the surgical decision whether to perform a wide debridement or to proceed with some instrumentations. The encouraging ROSE assistance dissuades surgeon for a second surgery thus benefits the patient economically.

The 15 cases were reported as 8 negative neoplasma, consisted of normal host cell population (mature bone, chondroid, fibrous, marrow cells population, and some mature inflammation cells) (fig.1e). All negative neoplasma cases were proceed for vertebroplasty or Kyphoplasty where bone filler was injected to elevate the compressed vertebral body. Four cases were malignant lesions; including 2 metastatic carcinomas (fig.1d) and 2 others were primary bone malignancy; a plasmacytoma (fig.1c) and a 
Non-Hodgkin Lymphoma (fig.1b). All of these four cases were ensured to get adequate samples for further immunohistochemistry or other ancillary studies, when need.

Among the three granulomatic tuberculosis cases were confirmed by positive rapid Ziehl Neelsen stained for Acid-Fast Bacilli (fig.1f). The operative management of non-tuberculosis and tuberculosis infection were different thus, ROSE evaluation method will assure the right management for the patients.

All ROSE examination of the cases was further confirmed by regular histopathology evaluation, which turn out to be accurate (table 1). Three to 24 months follow-up has shown a well-being of the patients' management, that may confirm the right intraoperative decisions.

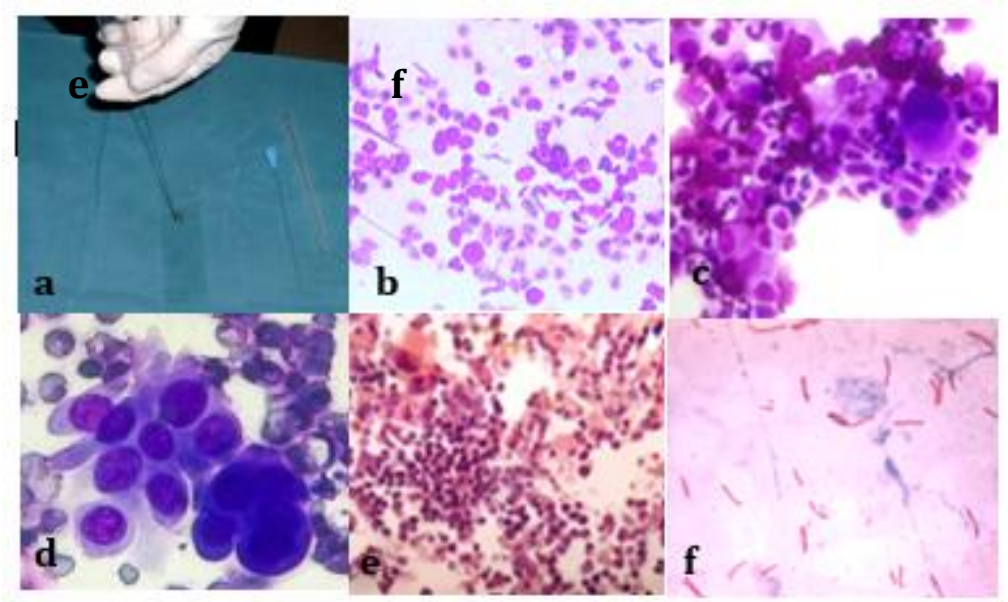

Figure 1. ROSE procedure and microscopic images of several cytology findings

a: trocar specimen is discharged into glass slide then stained with Diff Quik.

b: monotonous round cells of lymphoid anaplastic cells ; Non-Hodgkin Lymphoma (NHL)(400x)

c: various maturation of Plasma cell with eccentric round cartwheel nuclei (plasmacytoma; multiple myeloma)(400x)

d: cluster of anaplastic carcinoma (400x)

e: normal host marrow cell population (200x)

f: Acid Fast Bacilli, Ziehl Neelsen staining (1000x)

Table 1. The Spinal Lesion Cases

\begin{tabular}{|c|c|c|c|c|c|c|}
\hline no & Sex/age & $\begin{array}{c}\text { Lesion } \\
\text { site }\end{array}$ & Procedure & IOC result & $\begin{array}{c}\text { HPA } \\
\text { post IOC }\end{array}$ & F.U \\
\hline 1 & F/64 & $\begin{array}{c}\text { Vertebrae } \\
\text { Th } 12\end{array}$ & $\begin{array}{c}\text { Biopsy prior } \\
\text { vertebroplasty }\end{array}$ & $\begin{array}{c}\text { Negative } \\
\text { neoplasma } \\
\text { NHPC }\end{array}$ & $\begin{array}{c}\text { Negative } \\
\text { neoplasma }\end{array}$ & 24 \\
\hline 2 & F/64 & Vertebrae & biopsy & Non lesional & Negative & 6 \\
\hline
\end{tabular}




\begin{tabular}{|c|c|c|c|c|c|c|}
\hline & & L5 & & NHPC & neoplasma & \\
\hline 3 & $\mathrm{~F} / 64$ & $\begin{array}{c}\text { Vertebrae } \\
\text { Th } 12\end{array}$ & biopsy & $\begin{array}{l}\text { Round cell tumor } \\
\text { DD: NHL }\end{array}$ & $\begin{array}{l}\text { Non-Hodgkin } \\
\text { Lymphoma } \\
\text { (NHL) }\end{array}$ & 8 \\
\hline 4 & $\mathrm{M} / 63$ & $\begin{array}{l}\text { Vertebrae } \\
\text { L2 }\end{array}$ & $\begin{array}{l}\text { Biopsy prior } \\
\text { vertebroplasty }\end{array}$ & $\begin{array}{c}\text { Negative } \\
\text { neoplasma } \\
\text { NHPC }\end{array}$ & $\begin{array}{c}\text { Negative } \\
\text { neoplasma }\end{array}$ & 23 \\
\hline 5 & $\mathrm{M} / 89$ & $\begin{array}{c}\text { Vertebrae } \\
\text { Th } 12\end{array}$ & $\begin{array}{l}\text { Biopsy prior } \\
\text { vertebroplasty }\end{array}$ & $\begin{array}{c}\text { Negative } \\
\text { neoplasma } \\
\text { NHPC }\end{array}$ & $\begin{array}{l}\text { Negative } \\
\text { neoplasma }\end{array}$ & 18 \\
\hline 6 & $\mathrm{~F} / 81$ & $\begin{array}{l}\text { Vertebrae } \\
\text { L5 }\end{array}$ & $\begin{array}{l}\text { Biopsy prior } \\
\text { vertebroplasty }\end{array}$ & $\begin{array}{c}\text { Negative } \\
\text { neoplasma } \\
\text { NHPC }\end{array}$ & $\begin{array}{c}\text { Negative } \\
\text { neoplasma }\end{array}$ & 15 \\
\hline 7 & $\mathrm{~F} / 80$ & $\begin{array}{c}\text { Vertebrae } \\
\text { Th } 12\end{array}$ & $\begin{array}{l}\text { Biopsy prior } \\
\text { vertebroplasty }\end{array}$ & $\begin{array}{c}\text { Negative } \\
\text { neoplasma } \\
\text { NHPC }\end{array}$ & $\begin{array}{l}\text { Negative } \\
\text { neoplasma }\end{array}$ & 23 \\
\hline 8 & $\mathrm{M} / 25$ & $\begin{array}{l}\text { Vertebrae } \\
\text { L3 }\end{array}$ & debridement & $\begin{array}{l}\text { TB process; } \\
\text { positive } \\
\text { acid fast bacilli }\end{array}$ & TB process & 10 \\
\hline 9 & $\mathrm{M} / 24$ & $\begin{array}{c}\text { Vertebrae } \\
\text { Th } 12\end{array}$ & Debridement & $\begin{array}{l}\text { TB process; } \\
\text { positive } \\
\text { acid fast bacilli }\end{array}$ & TB process & 4 \\
\hline 10 & $\mathrm{M} / 40$ & $\begin{array}{l}\text { Vertebrae } \\
\text { L2 }\end{array}$ & biopsy & $\begin{array}{l}\text { Round cell tumor; } \\
\text { plasmacytoma }\end{array}$ & $\begin{array}{l}\text { Plasmacytoma; } \\
\text { multiple myeloma }\end{array}$ & 14 \\
\hline 11 & $\mathrm{~F} / 67$ & $\begin{array}{l}\text { Vertebrae } \\
\text { L2 }\end{array}$ & biopsy & $\begin{array}{l}\text { Round cell tumor; } \\
\text { susp adrenal tumor }\end{array}$ & $\begin{array}{c}\text { Metastases } \\
\text { adrenal carcinoma }\end{array}$ & 12 \\
\hline 12 & $\mathrm{~F} / 39$ & $\begin{array}{c}\text { Vertebrae } \\
\text { sacrum }\end{array}$ & biopsy & $\begin{array}{l}\text { Present anaplastic } \\
\text { cell, suspicious } \\
\text { carcinoma }\end{array}$ & $\begin{array}{l}\text { Metastases } \\
\text { carcinoma }\end{array}$ & 3 \\
\hline 13 & $\mathrm{~F} / 15$ & $\begin{array}{c}\text { Vertebrae } \\
\text { Th } 12\end{array}$ & Debridement & $\begin{array}{l}\text { TB process; } \\
\text { positive } \\
\text { acid fast bacilli }\end{array}$ & TB process & 3 \\
\hline 14 & $\mathrm{~F} / 61$ & $\begin{array}{l}\text { Vertebrae } \\
\text { L2 }\end{array}$ & $\begin{array}{l}\text { Biopsy prior } \\
\text { vertebroplasty }\end{array}$ & $\begin{array}{c}\text { Negative } \\
\text { neoplasma } \\
\text { NHPC }\end{array}$ & $\begin{array}{l}\text { Negative } \\
\text { neoplasma }\end{array}$ & 3 \\
\hline 15 & $\mathrm{M} / 62$ & $\begin{array}{l}\text { Vertebrae } \\
\text { L2 }\end{array}$ & $\begin{array}{l}\text { Biopsy prior } \\
\text { vertebroplasty }\end{array}$ & $\begin{array}{c}\text { Negative } \\
\text { neoplasma } \\
\text { NHPC }\end{array}$ & $\begin{array}{c}\text { Negative } \\
\text { neoplasma }\end{array}$ & 4 \\
\hline
\end{tabular}

F: female, M: male, Th: thoracal, L: lumbal, TB: Tuberculoses, 
IOC: Intraoperative Cytology, HPA: Histopathology Anatomy,

FNAB: Fine Needle Aspiration Biopsy,

NHPC: Normal Host Population Cells

F.U: follow-up (in months)

\section{Discussion:}

Since needle biopsy (fine needle or core biopsy) has been accepted as a standard diagnostic procedure, ROSE has become a bridging technique or procedure. $^{2,8,9}$ Several times the operator of the biopsy could not decide whether the specimens has arrived from the correct lesion or whether the amount of the specimens is adequate enough for diagnostic and ancillary test afterward. ${ }^{3,5,7}$ The consequences of unsampled specimens are additional open biopsy, rebiopsy, or undiagnosed case; which will risk a higher cost for the patients or insurance company; not to mention the psychological effects for the patient and the doctor as well. ${ }^{3,5,8,9}$

ROSE may help surgeon or radiologist, especially in percutaneous endoscopic biopsy, or endoscopic ultrasound guided to decide whether the procedure has reached the suspicious lesion and obtained adequate material to be diagnosed; or whether another pass should be considered for better sampling areas. In thyroid nodules, FNAB with ROSE yielded $92 \%$ adequacy rates, compared to $83 \%$ without ROSE. $^{9}$ In sophisticated expensive procedure like endoscopic guided ultra sound (EUS), a confirmation of highly adequate sampling in the correct lesional area is a must. ROSE has increased the adequacy rate (the rate of sufficient and reliable sample specimens) by $12 \%$ and has now been acquired as a standard procedure. ${ }^{10,11,12}$

In a large study of 214 CT-guided percutaneous FNA prior to surgery, has changed the management of patients in $50 \%$ cases. Not in all lesions CT-guided FNAB could be performed. ${ }^{7}$ When the periosteum is intact, there would be no needle access. In our cases, ROSE was required when the surgeons needs guidance to decide between two options during surgery; to avoid unnecessary second surgery, which usually has terrible obstacle and lots of reluctance. 3,7,9,12 $^{3}$ Vertebral compression fracture in elderly harbored as a consequence of severe osteoporosis or lytic process. ${ }^{6,7}$ These can be due to a physiological aging process or a pathological consequences of direct malignancy metastases or indirect malignancy therapeutic adverse effect of the chemotherapy, radiotherapy, or the steroid treatment. ${ }^{4,6,7}$ A routine biopsy 
prior to vertebroplasty or Kyphoplasty procedure in every vertebral compression fracture has been a protocol in our institution.

\section{CONCLUSION}

The role of ROSE in spinal lesion surgery is to assure a reliable and adequate sampling biopsy material to be diagnosed, which contribute to the consideration for the right surgical management and decision intraoperatively.

\section{ACKNOWLEDGEMENT}

The authors would like to thank all operating theater staffs, laboratory staffs, and medical record staff of Surabaya Orthopedi \& Traumatology Hospital.

\section{CONFLICT OF INTEREST}

The authors affirm no conflict of interest in this study

\section{REFERENCES}

1. Mody DR, Thrall MJ, Krishnamurthy S. Diagnostic Pathology. Cytopathology $2^{\text {nd }}$ ed. 2018. Salt lake City, UT. Elsevier

2. Schmidt R.L., Witt B.L., LopezCalderon L.E., Layfield L.J. The Influence of Rapid Onsite Evaluation on the Adequacy Rate of Fine-Needle Aspiration Cytology: A Systematic Review and Meta-Analysis. Am J Clin Pathol. 2013;139: 300-308.
3. Nasuti JF, Gupta PK, Baloch ZW. Diagnostic value and costeffectiveness of on-site evaluation of fine-needle aspiration specimens: Review of 5,688 cases. Diagn Cytopathol. 2002;27:1-4

4. Aithala PJ. Role of Percutaneous Image Guided Biopsy in Spinal Lesions: Adequacy and Correlation with MRI Findings. J Clin Diagn Res. 2016 Aug; 10(8): RC11-RC15.

5. Stevenson T, Powari M, Bowles C. Evolution of a rapid onsite evaluation (ROSE) service for endobronchial ultrasound guided (EBUS) fine needle aspiration (FNA) cytology in a UK Hospital: A 7year audit. Diagn Cytopathol. 2018: 13

6. Muthukumar N. Biopsy of Osteoporotic Vertebral Compression Fracture. Neurol.India 2013;61: 569571

7. Rehm J, Veith S, Akbar M etal. CTGuided Percutaneous Spine Biopsy in Suspected Infection or Malignancy: A Study of 214 Patients. Fortschr Röntgenstr 2016; 188: 1156-1162

8. Mallya V., Kumar S.P., Meganathan P., Shivkumar S., Mehta R. The Utility of ROSE (Rapid On-Site Evaluation) in Endobronchial Ultrasound (EBUS)Guided Transbronchial Needle 
Aspiration (TBNA): Is the Picture

Rosy? J Cytol 2015;32(4): 230-233

9. Witt B.L., Schmidt R.L. Rapid Onsite Evaluation Improves the Adequacy of Fine-Needle Aspiration for Thyroid Lesions: A Systematic Review and Meta-Analysis. Thyroid 2013;23:4

10. Meena N., Jeffus S., Massol N., Siegel E., Korourian S., Chen C., Bartter T. Rapid Onsite Evaluation: A Comparison of Cytopathologist and Pulmonologist Performance. Cancer Cytopathology. 2016;124:279-284

11. Jain Deeali et al. Rapid On-Site Evaluation of Endobronchial
Ultrasound-Guided Transbronchial Needle Aspirations for the Diagnosis of Lung Cancer. A Perspective From Members of the Pulmonary Pathology Society. Arch Pathol Lab Med. 2018;142:253-262

12. Hassan M. Rapid On-site Evaluation: What a Microscope will add to the Bronchoscopy Unit? A Concise Review. Egypt J Bronchol 2016;10:206-211 